\title{
Research Article \\ Correlation Analysis of Antioxidant Activities with Tannin, Total Flavonoid, and Total Phenolic Contents of Nutmeg (Myristica fragrans Houtt) Fruit Precipitated by Egg white
}

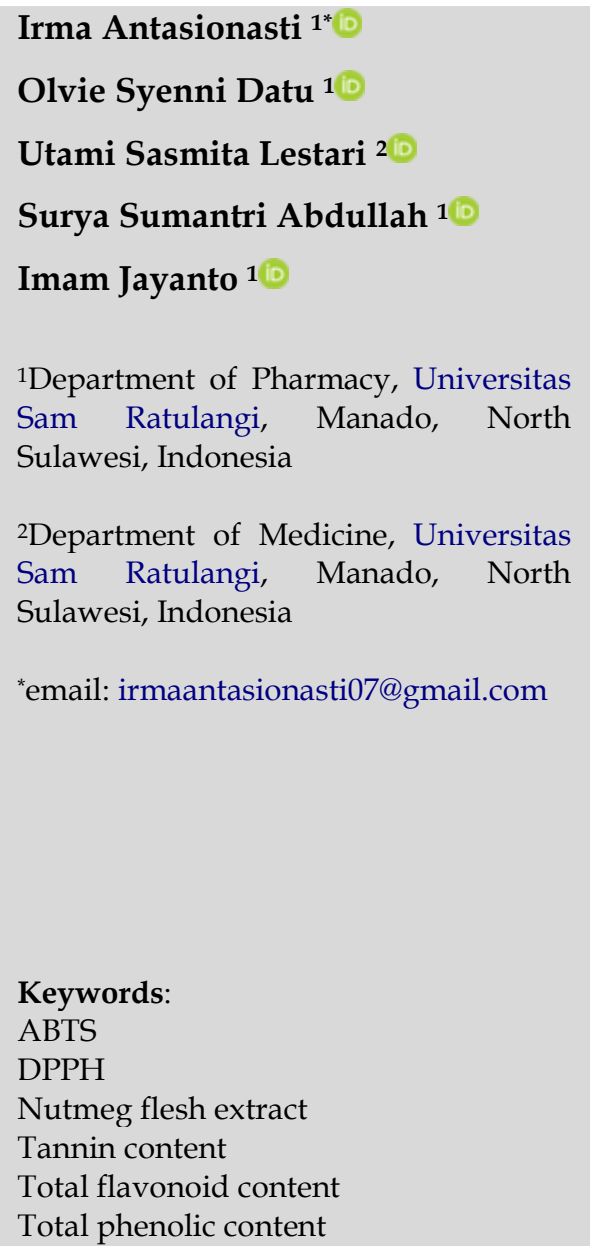

\begin{abstract}
The nutmeg (Myristica fragrans) flesh extract has a strong antioxidant activity. Therefore, $M$. fragrans flesh can be developed for functional drinks which are sources rich in antioxidants good for the prevention and treatment of diseases such as cancer and cardiovascular diseases. However, the tannins' content can cause a bitter and sour taste. Therefore, the tannins content should be reduced by the addition of egg white. The purpose of this study is to find out the comparison of antioxidant activity between a combination of $M$. fragrans flesh extract with various concentrations of egg white and to correlate its antioxidant activities with tannin, total flavonoid, and total phenolic contents. The antioxidant activities were conducted on $M$. fragrans flesh extract by using DPPH and ABTS radicals. Tannin, total flavonoid, and total phenolic contents from $M$. fragrans flesh extract were also tested. The $M$. fragrans flesh extracts without addition egg white have a strong antioxidant in scavenging the stable free radical ABTS $(89.980 \pm 0.480 \mu \mathrm{g} / \mathrm{mL})$ and intermediate antioxidant in scavenging the stable free radical DPPH $(105.669 \pm 0.102 \mu \mathrm{g} / \mathrm{mL})$. It is followed accordingly by tannin, total flavonoid, and total phenolic contents, namely $14.034 \pm 0.100 \% \mathrm{w} / \mathrm{w}$ TAE, $26.929 \pm 0.129 \% \mathrm{w} / \mathrm{w} \mathrm{QE}$, and $53.164 \pm 0.129 \% \mathrm{w} / \mathrm{w}$ GAE, respectively. Correlation of tannin, total flavonoid, and total phenolic contents, which inhibited DPPH and ABTS radicals had R2 values of about $89.23-97.63 \%$. It showed that antioxidant activity is strongly influenced by the tannin, total flavonoid, and total phenolic contents. Therefore, precipitation from the tannin-protein bond caused antioxidant activities were decreased.
\end{abstract}

Received: June $28^{\text {th }}, 2021$

Accepted: October 6 ${ }^{\text {th }}, 2021$

Published: November 30th, 2021

(c) 2021 Irma Antasionasti, Olvie Syenni Datu, Utami Sasmita Lestari, Surya Sumantri Abdullah, Imam Jayanto. Published by Institute for Research and Community Services Universitas Muhammadiyah Palangkaraya. This is an Open Access article under the CC-BY-SA License (http://creativecommons.org/licenses/by-sa/4.0/). DOI: https:// doi.org/10.33084/bjop.v4i4.2497

\section{INTRODUCTION}

Nutmeg (Myristica fragrans Houtt.) originated in the Banda Islands of Indonesiaํ․ It has many applications in the culinary, pharmaceutical, and cosmetic industries². However, after the seeds and maces took, M. fragrans flesh was not utilized optimally and became waste. Therefore, M. fragrans flesh can be developed for functional drinks, which are sources rich in antioxidants good for preventing and treating diseases such as cancer and cardiovascular diseases ${ }^{3,4}$.

The antioxidant activity of several parts of $M$. fragrans has been established by much research ${ }^{4-9}$. The antioxidant activity of $M$. fragrans seed was the most reported that seed had the greatest reducing property and radical scavenging ability compared to other parts of $M$. fragrans $^{4}$. However, Ginting et al. ${ }^{8}$ reported that extract of M. fragrans flesh had the most significant antioxidant 
activity compared to the seed. Antioxidant properties contributed by the variety of active phytochemicals from its essential oil ${ }^{1,8}$, including saponin, alkaloid, tannin, flavonoids, a-pinene, $\beta$-pinene, myrcene, 1,8-cineole, carvacrol, terpinen-4-ol, sabinene, camphene, myristicin, elemicin, isoelemicin, eugenol, isoeugenol, methoxyeugenol, safrole, and lignan 7,8,10-13.

Myristica fragrans fruit contains tannin compounds that can cause a bitter and sour taste for the functional drinks to be developed. Therefore, the level of tannins should be reduced by adding flocculant substances from egg white albumin $^{14}$. Reduced tannins can cause a decrease in antioxidant activity because tannins could be a natural source as an effective natural antioxidant compound ${ }^{15-18}$. Antioxidant activity of plant extracts correlated with the number of their phenolic compounds that tannin is a phenolic compound ${ }^{19,20}$. Gupta and Rajpurohit ${ }^{1}$ reported that total phenolic content and antioxidant activity have a significant and positive correlation. Besides that, analysis of the correlation with total flavonoid content in which it is the largest group of compounds in the phenolic group should be done. It had been reported that antiradical scavenging has a significantly high level of phenolic and flavonoid content ${ }^{21,22}$.

Vivia et al. ${ }^{14}$ reported that egg white concentration significantly affected $\mathrm{pH}$, titratable acidity, precipitate percentage, and organoleptic. This indicates that the correlation between tannin precipitation and antioxidant activity has not been studied. Therefore, the purpose of this study is to find out the comparison of antioxidant activity between the combination of $M$. fragrans flesh extract with various concentrations of egg white consisting of $0,1,2,3,4$, and $5 \%$, as well as to correlate its antioxidant activities with tannin, total flavonoid, and total phenolic contents.

\section{MATERIALS AND METHODS}

\section{Materials}

Myristica fragrans fruit (Figure 1) obtained from Sangihe Island of North Sulawesi, Indonesia and determination carried out in a Biology Laboratory, Faculty of Math and Science, Universitas Sam Ratulangi with a certificate number of $70 / \mathrm{LBD} .11 / \mathrm{IT} / 2021$. The result of the determination states that the plants used in this study were Myristica fragrans Houtt from the family Myrtaceae. This study also used chemical reagents such as 2,2diphenyl-1-picrylhydrazyl (DPPH, Sigma-Aldrich), 2,2'azino-bis-3-ethylbenzothiazoline-6-sulfonic acid (ABTS, Sigma-Aldrich), potassium persulfate (Sigma-Aldrich), ethanol p.a. (Merck), tannic acid (Merck), sodium tungstate (Sigma-Aldrich), phosphomolybdic acid (Sigma-Aldrich), phosphoric acid (Sigma-Aldrich), natrium carbonate (Merck), gallic acid (Sigma-Aldrich), Folin-Ciocalteu (Merck), quercetin (Sigma-Aldrich), natrium nitrite (Merck), natrium hydroxide (Merck), aquadest (Bratachem), and water (Danone).

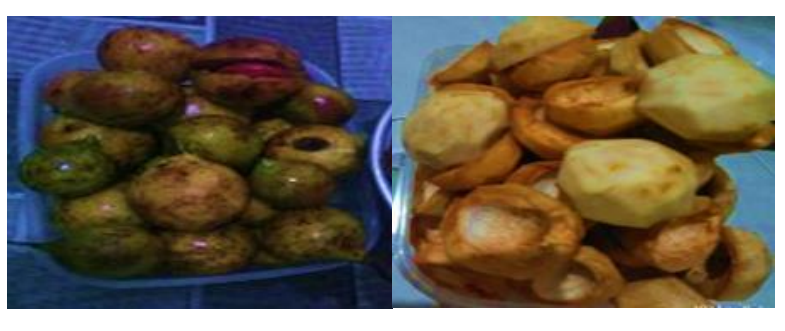

a b

Figure 1. Myristica fragrans whole fruit (a) and its flesh (b)

\section{Methods}

\section{Preparation of aqueous extract}

Myristica fragrans have been cut into small pieces extracted with water with a sample : solvent ratio of 1:3 $\mathrm{w} / \mathrm{v}^{23}$. The resulting $M$. fragrans extract was heated at a temperature of $80^{\circ} \mathrm{C}$ and added egg white with a concentration of $0,1,2,3,4$, and $5 \%$ while stirring. Then, it was silenced and extracted again to separate the white dregs eggs and $M$. fragrans extract ${ }^{14}$. The $M$. fragrans 
extract was obtained then dried using an oven at a temperature of $50^{\circ} \mathrm{C}$ until a constant weight was obtained.

\section{Determination of antioxidant activity with DPPH}

Antioxidant activity of DPPH radical of samples was performed based on Kikuzaki et al. ${ }^{24}$ with modified. In this assay, as much as $1 \mathrm{~mL}$ from each sample solution was briefly taken and added with $3 \mathrm{~mL}$ ethanol p.a., then $1 \mathrm{~mL}$ of $0.4 \mathrm{mM} \mathrm{DPPH}$. The mixture was shaken vigorously using vortex for 1 minute and was allowed to stand for 15 minutes at $25^{\circ} \mathrm{C}$ in the darkroom. The absorbance of each solution was measured using a spectrophotometer at $517 \mathrm{~nm}$ using ethanol as blank. The antioxidant activity was calculated as $\mathrm{IC}_{50}$ value. The $\mathrm{IC}_{50}$ value was obtained from a linear regression equation that plotted the percentage of inhibition with the concentration $(\mu \mathrm{g} / \mathrm{mL})$. The equation [1] calculated the percentage of inhibition:

$$
\% \text { inhibition }=\left(\frac{A b s_{\text {control }}-A b s_{\text {Sample }}}{A b s_{\text {control }}}\right) \times 100 \%
$$

\section{Determination of antioxidant activity with ABTS}

Antioxidant activity of ABTS radical of samples was performed based on Aktumsek et al. ${ }^{25}$ with slightly modified. Briefly, ABTS radical cation was produced by reacting $28.406 \mathrm{mg}$ of ABTS and $14 \mathrm{mg}$ of potassium persulfate in $20 \mathrm{~mL}$ of aquadest. The mixture was allowed to stand for 16 hours at room temperature and then added aquadest until $100 \mathrm{~mL}$. As much as $1 \mathrm{~mL}$ from each sample solution was briefly taken and added with $3 \mathrm{~mL}$ of aquadest then $1 \mathrm{~mL}$ of ABTS. The mixture was shaken vigorously using vortex for 1 minute and allowed to stand for 10 minutes at $25^{\circ} \mathrm{C}$ in a darkroom. The absorbance of each solution was measured using a spectrophotometer at $730 \mathrm{~nm}$ using aquadest as blank. The antioxidant activity was calculated as $\mathrm{IC}_{50}$ value. The $\mathrm{IC}_{50}$ value was obtained from a linear regression equation that plotted the percentage of inhibition with the concentration $(\mu \mathrm{g} / \mathrm{mL})$. The equation [1] calculated the percentage of inhibition.

\section{Determination of tannin content}

The tannin content of samples was performed based on Pratama et al. ${ }^{26}$ As much as $2 \mathrm{~mL}$ from each sample solution was briefly taken and added with $2 \mathrm{~mL}$ FolinCiocalteu reagent. The mixture was stood for 3 minutes, then added $2 \mathrm{~mL}$ of $7,5 \% \mathrm{Na}_{2} \mathrm{CO}_{3}$. The mixture stood for 40 minutes. The absorbance of the mixture was determined at $654 \mathrm{~nm}$ versus a blank containing all reagents except the samples. The absorption of standard tannin solutions was measured under the same conditions for making a calibration curve. All determinations were carried out in triplicates. The number of tannin contents in samples was expressed as $\mathrm{g}$ tannic acid equivalents (TAE) $/ 100 \mathrm{~g}$ of sample (\%w/w TAE).

\section{Determination of total phenolic content}

Total phenolic content of samples was performed based on Chun et al. ${ }^{27}$ As much as $1 \mathrm{~mL}$ from each sample solution was briefly taken and added with $0.4 \mathrm{~mL}$ FolinCiocalteau reagent. The mixture was stood for 5 minutes, then added $4 \mathrm{~mL}$ of $7 \% \mathrm{Na}_{2} \mathrm{CO}_{3}$ and aquadest until 10 $\mathrm{mL}$. The mixture stood for 2 hours. The absorbance of the mixture was determined at $755 \mathrm{~nm}$ versus a blank containing all reagents except the samples. The absorption of standard phenolic solutions was measured under the same conditions for making a calibration curve. All determinations were carried out in triplicates. The amount of total phenolic contents in samples was expressed as $\mathrm{g}$ gallic acid equivalents (GAE)/100 $\mathrm{g}$ of sample (\%w/w GAE).

\section{Determination of total flavonoid content}

The total flavonoid content of samples was performed based on Zou et al. ${ }^{28}$ As much as $1 \mathrm{~mL}$ from each sample solution was briefly taken and added with $4 \mathrm{~mL}$ aquadest and $0.3 \mathrm{~mL}$ of $10 \% \mathrm{NaNO}_{2}$. The mixture was stood for 6 
minutes, then added with $0.3 \mathrm{~mL}$ of $10 \% \mathrm{AlCl}_{3}, 4 \mathrm{~mL}$ of $10 \% \mathrm{NaOH}$, and aquadest until $10 \mathrm{~mL}$. The mixture stood for 15 minutes. The absorbance of the mixture was determined at $495 \mathrm{~nm}$ versus a blank containing all reagents except the samples. The absorption of standard flavonoid solutions was measured under the same conditions for making a calibration curve. All determinations were carried out in triplicates. The number of total flavonoid contents in samples was expressed as $\mathrm{g}$ quercetin equivalents (QE)/100 $\mathrm{g}$ of sample (\%w/w QE).

\section{Statistical analysis}

All data were presented as mean \pm standard deviation (SD) for at least three replications for each sample. Statistical analysis was performed based on the independent sample T-test level 95\% using SPSS (SPSS Corporation, Chicago, IL) version 16.0 for Windows. Linear regression to correlate between total phenolics and total flavonoid with antioxidant activities was carried using Microsoft Excel 2010.

\section{RESULTS AND DISCUSSION}

\section{Antioxidant activity of Myristica fragrans flesh extract}

Antioxidant activity of $M$. fragrans flesh extract (MfFE) can be measured by several methods, such as the capacity to scavenge the stable free radical (DPPH and ABTS), ferric reducing/antioxidant power assay (FRAP), chelating agent, inhibition of lipid peroxidation, inhibition of bleaching of $\beta$-carotene, and other ${ }^{1,22}$. In this study, the antioxidant activity of MfFE was measured by the capacity to scavenge the stable free radical (DPPH and ABTS). Using the DPPH method, the MfFE showed free radical scavenging activity based on its ability to donate hydrogen atoms ${ }^{29}$, reducing the purple color of the DPPH solution at a wavelength of $517 \mathrm{~nm}^{30}$. The decrease in absorbance value can be seen visually with changes in color from purple to yellow. In the ABTS method, the MfFE showed free radical scavenging activity based on stabilizing free radicals by donating proton radicals ${ }^{29}$. The antioxidant activity of MfFE using DPPH and ABTS radical was evaluated based on inhibitory concentration $\left(\mathrm{IC}_{50}\right)$ parameters, as seen in Table I.

Table I showed the $\mathrm{IC}_{50}$ value of MfFE classified in the category of strong antioxidant ${ }^{31}$ in scavenging the stable free radical ABTS ( $0 \%$ MfFE), an intermediate antioxidant in scavenging the stable free radical DPPH (0\% MfFE), and weak antioxidant for another sample in scavenging the stable free radical DPPH and ABTS31. The antioxidant activity of the samples was not better than ascorbic acid's antioxidant activity. However, the antioxidant activity of sample $0 \% \mathrm{MfFE}$ in this research was more potent than the antioxidant activity reported by Assa et al. ${ }^{32}$, Ginting et al. ${ }^{8}$, and Selonni33 ${ }^{33}$ This can be influenced by the different areas of the sample collected, the solvent, and the extraction method used. The sample obtained by Ginting et al. ${ }^{8}$ and Selonni ${ }^{33}$ comes from outside North Sulawesi. Ginting et al. ${ }^{8}$ reported that samples of MfFE were extracted using the water distillation method to produce essential oils. This caused the antioxidant activity to be influenced by the compounds contained in the essential oil. Selonni ${ }^{33}$ reported that samples of $M$. fragrans flesh extracted using maceration method with solvent ethanol $70 \%$ has better antioxidant activity $\left(\mathrm{IC}_{50} 219.2 \mu \mathrm{g} / \mathrm{mL}\right)$ than Ginting et al. ${ }^{8}$ This can be influenced by the extracted components, not just the essential oil. Antioxidant activity reported by Assa et al. ${ }^{32}(1372.91 \mu \mathrm{g} / \mathrm{mL})$ is lower than all, even though the samples were from the same province as the samples in this study. Assa et al. ${ }^{32}$ reported that samples dried before extraction, whereas this study used fresh samples. The sample drying process can damage compounds that contribute as antioxidants ${ }^{34}$. 
Table I. Antioxidant activity of $M$. fragrans flesh extract

\begin{tabular}{lcc}
\hline \multirow{2}{*}{ Sample } & \multicolumn{2}{c}{ Antioxidant activity } \\
\cline { 2 - 3 } & $\begin{array}{c}\text { DPPH }- \text { IC }_{50} \pm \text { SD } \\
(\mu \mathrm{g} / \mathbf{m L})\end{array}$ & $\begin{array}{c}\text { ABTS }-\mathbf{I C}_{50} \pm \text { SD } \\
(\mu \mathrm{g} / \mathrm{mL})\end{array}$ \\
\hline $0 \% \mathrm{MfFE}{ }^{*}$ & $105.669 \pm 0.102$ & $89.980 \pm 0.480$ \\
$1 \% \mathrm{MfFE}{ }^{* *}$ & $252.668 \pm 4.137$ & $252.163 \pm 1.418$ \\
$2 \% \mathrm{MfFE}$ & $299.543 \pm 1.487$ & $313.523 \pm 2.956$ \\
$3 \% \mathrm{MfFE}$ & $365.568 \pm 1.593$ & $348.755 \pm 7.400$ \\
$4 \% \mathrm{MfFE}$ & $381.047 \pm 2.417$ & $389.138 \pm 6.886$ \\
$5 \% \mathrm{MfFE}$ & $387.536 \pm 1.687$ & $481.778 \pm 2.124$ \\
Ascorbic acid & $0.539 \pm 0.001$ & $0.699 \pm 0.004$ \\
${ }^{*} M$. fragrans flesh extract without egg white addition; ${ }^{* *} M$. \\
fragrans flesh extract with $1 \%$ egg white addition, and so on
\end{tabular}

Myristica fragrans flesh extract has different antioxidant activities based on two methods of DPPH and ABTS. The statistical test showed the mean of each group in the DPPH method was $2.5608 \times 10^{2}$, which was lower than ABTS with $2.6801 \times 10^{2}$ but not significantly different $(\mathrm{p}$ $>0.05$ ). This can be caused by the radical's mechanism reaction. The DPPH and ABTS assays are classified as Single Electron Transfer (SET) reactions ${ }^{35}$. The different results reported by Martysiak-Żurowska and Wenta ${ }^{36}$, with the total antioxidant capacity of human milk determined by the ABTS method, were significantly higher than those reported in the DPPH assay. It can be affected by the difference in the solvent used. MartysiakŻurowska and Wenta ${ }^{36}$ used methanol to dissolve $\mathrm{DPPH}$, but in this research used ethanol p.a. Methanol is a solvent with reactions in strong hydrogen-bonding, which interferes with the release of hydrogen atoms, thus enormously enhancing SET over Hydrogen Atom Transfer (HAT) ${ }^{37}$.

According to Table I, the antioxidant activity of samples was decreased with the addition of egg white. This situation can happen because polyphenols compound can affect interaction with protein from egg white by a covalent and non-covalent bond so that higher concentration of egg white added to the $M$. fragrans flesh extract caused stronger interaction between polyphenols and protein ${ }^{3841}$. McRae and Kennedy ${ }^{42}$ reported that the protein's binding mechanism of polyphenols (tannins) is divided into three different stages, which occur by the presence of ionic bonds, hydrophobic interactions, and hydrogen bonds. Ionic bonds occur on the cation side (as a protons compound receptor) from proteins $\left(\mathrm{NH}_{3}{ }^{+}\right)$and a negatively charged hydroxyl group (as a proton donor) from tannin compounds (O). Hydrophobic interactions occur between the aromatic ring of polyphenols with the pyrrolidine group, which is the hydrophobic side of the protein. Hydrogen bonds occur between the hydroxyl $(\mathrm{OH})$ groups of phenolic compounds (tannins) and the carboxyl group (COO) of the protein. The bond formed causes the polyphenols content to decrease when the egg white is filtered. In this case, the content of tannins, which are polyphenol compounds, is expected to decrease to reduce the sour and bitter taste in the development of functional drinks.

Correlation analysis of antioxidant activities with tannin, total phenolic, and total flavonoid contents of Myristica fragrans flesh extract

This research showed that $M$. fragrans flesh extract contains condensed tannins. The condensed tannins precipitated using protein, such as egg white ${ }^{43}$. The higher concentration of egg white used causes more significant precipitation so that tannin, total phenolic, and total flavonoid contents of $M$. fragrans flesh extract decreased, as shown in Table II. Tannin contents expressed in tannic acid equivalents (TAE) (Figure 2), total phenolic contents expressed in gallic acid equivalents (GAE) (Figure 3), and total flavonoid contents expressed in quercetin equivalents $(\mathrm{QE})$ (Figure $4)$.

Table II. Tannin, total phenolic, and total flavonoid contents of $M$. fragrans flesh extract

\begin{tabular}{lrrr}
\hline Sample & $\begin{array}{c}\text { Tannin } \\
\text { content } \pm \text { SD } \\
(\% \text { w/w TAE) }\end{array}$ & $\begin{array}{c}\text { Total } \\
\text { content } \pm \text { SD } \\
\text { flow/w QE) }\end{array}$ & $\begin{array}{c}\text { Total } \\
\text { content } \pm \text { SD } \\
\text { (\%w/w GAE) }\end{array}$ \\
\hline 0\% MfFE & $14.034 \pm 0.100$ & $26.929 \pm 0.129$ & $53.164 \pm 0.129$ \\
1\% MfFE & $6.674 \pm 0.093$ & $16.080 \pm 0.146$ & $24.508 \pm 0.020$ \\
2\% MfFE & $4.934 \pm 0.015$ & $12.985 \pm 0.146$ & $17.483 \pm 0.020$ \\
3\% MfFE & $3.218 \pm 0.007$ & $11.523 \pm 0.080$ & $13.446 \pm 0.017$ \\
4\% MfFE & $3.142 \pm 0.008$ & $10.684 \pm 0.030$ & $12.448 \pm 0.017$ \\
$5 \%$ MfFE & $2.293 \pm 0.018$ & $8.255 \pm 0.064$ & $9.727 \pm 0.052$ \\
\hline
\end{tabular}




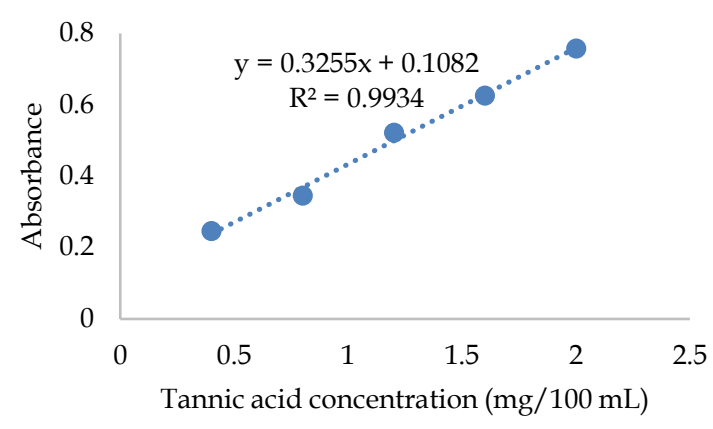

Figure 2. Calibration curve of standard tannic acid for determination of tannin content

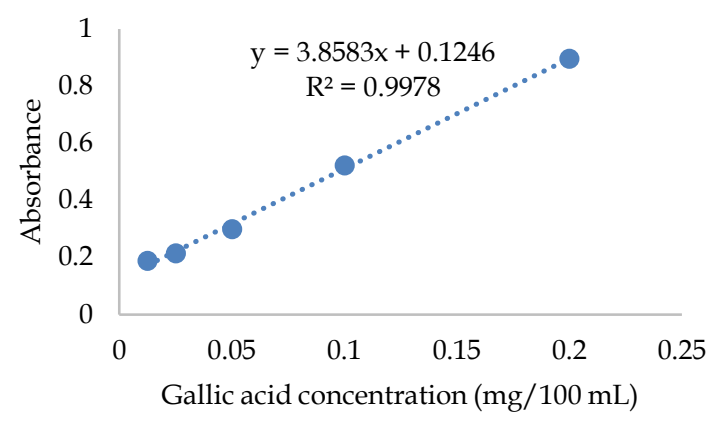

Figure 3. Calibration curve of standard gallic acid for determination of total phenolic content

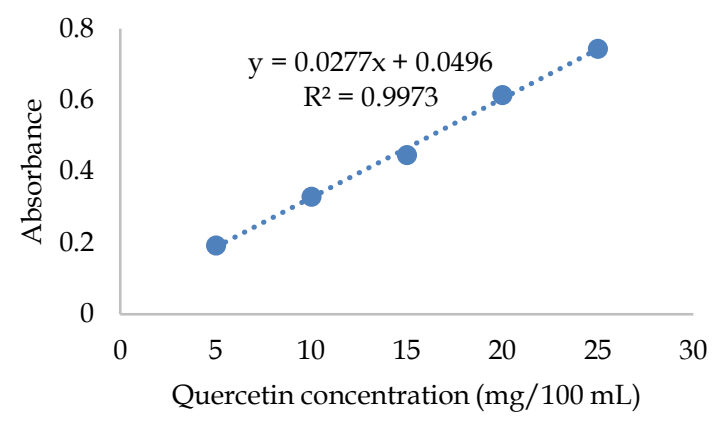

Figure 4. Calibration curve of standard quercetin for determination of total flavonoid content

Tannins are a flavonoid compound because its structure, which has two aromatic rings bonded by three carbon atoms $^{44}$. Flavonoids are a class of phenolic secondary metabolite compounds characterized by a benzo-pyrone structure $^{45}$. Reduced tannin contents caused the total phenolic and flavonoid contents to decrease. Therefore, tannin, total flavonoid, and total phenolic contents of $M$. fragrans flesh extract often correlated with its antioxidant activity $^{43,46}$. Its correlation could be seen in Figures 5 to 10 based on coefficient determination $\left(R^{2}\right)$ value.
The antioxidant mechanism of tannic acid is still far from being fully understood; therefore, it requires further investigation ${ }^{47}$. Figures 5 and 6 indicated that tannin compounds contributed $97.63 \%$ toward the DPPH radical scavenging and $90.91 \%$ toward the ABTS radical scavenging in the evaluated $M$. fragrans flesh extract. Figures 7 and 8 showed a correlation between radical scavenging activity and the total flavonoid contents of $M$. fragrans flesh extract, namely $96.68 \%$ for DPPH radical and $94.61 \%$ for ABTS radical. The antioxidant mechanism of flavonoids compounds as radical scavenging influenced by hydroxylation of ring $B$ and a C2-C3 double bond connected with a C-3 hydroxyl group and a C-4 carbonyl group, whereas hydroxylation of ring A also enhances the activity, as does the presence of gallate and galacturonate moieties as a substituent on the flavonoid skeleton ${ }^{48}$. The antioxidant mechanism of phenolic compounds neutralizes lipid free radicals and prevents the decomposition of hydroperoxides into free radicals ${ }^{21}$. Based on that mechanism was obtained, the results were in Figures 9 and 10. The correlation between radical scavenging activity of DPPH and ABTS with total phenolic contents of $M$. fragrans flesh extract was $95.91 \%$ and $89.23 \%$, respectively.

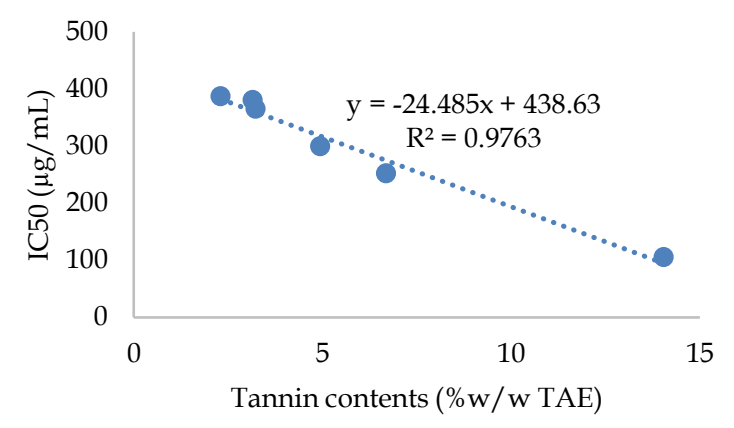

Figure 5. Correlation between radical scavenging activity of DPPH with tannin contents of $M$. fragrans flesh extract 


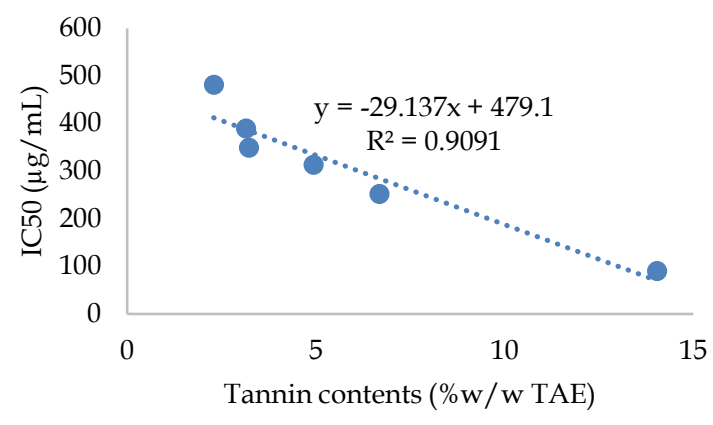

Figure 6. Correlation between radical scavenging activity of ABTS with tannin contents of $M$. fragrans flesh extract

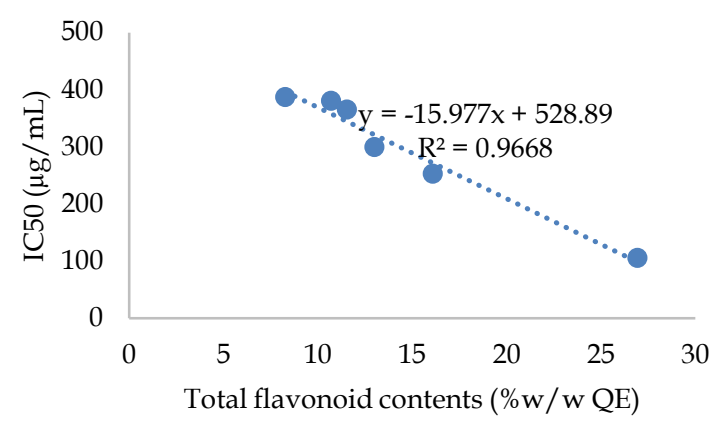

Figure 7. Correlation between radical scavenging activity of DPPH with total flavonoid contents of $M$. fragrans flesh extract

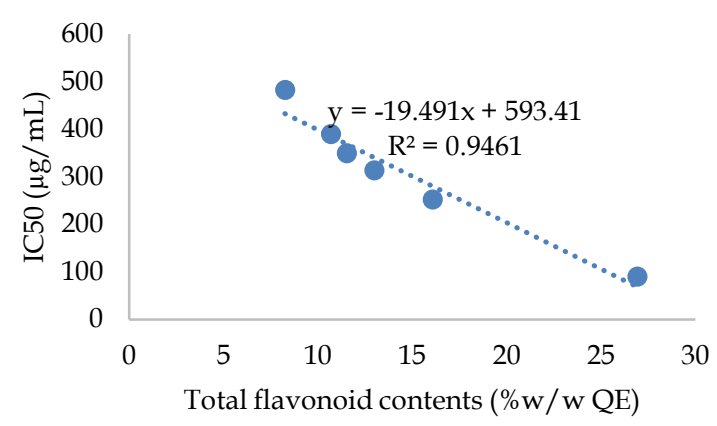

Figure 8. Correlation between radical scavenging activity of ABTS with total flavonoid contents of $M$. fragrans flesh extract

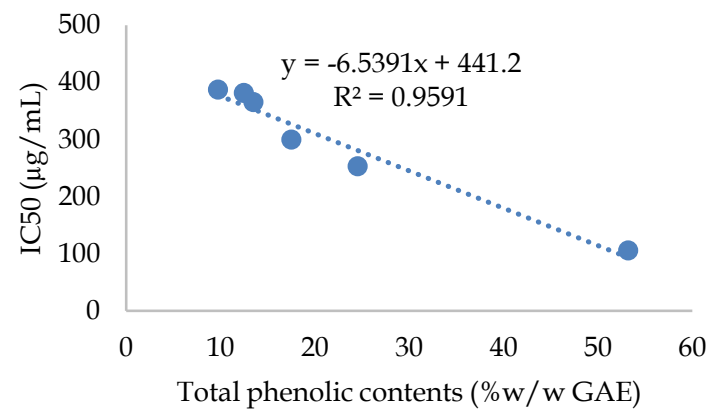

Figure 9. Correlation between radical scavenging activity of DPPH with total phenolic contents of $M$. fragrans flesh extract

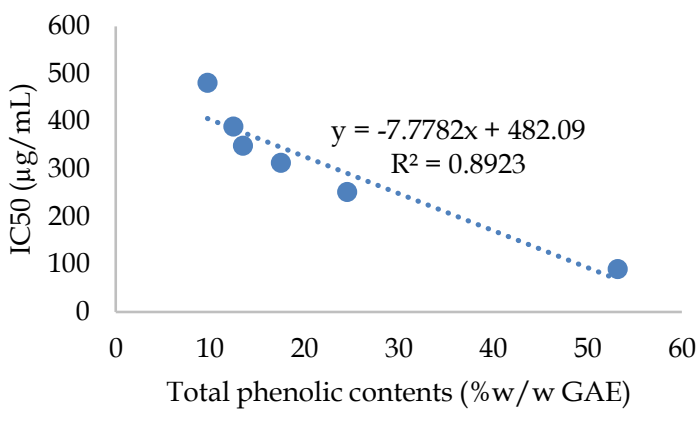

Figure 10. Correlation between radical scavenging activity of ABTS with total phenolic contents of $M$. fragrans flesh extract

Tannin, total flavonoid, and total phenolic contents contribute to inhibiting DPPH radicals than ABTS radicals. A similar result was discovered by our previous research $^{22}$ who had demonstrated that total flavonoid and total phenolic contents more contribute to the antioxidant activity by DPPH than the ABTS method. The antioxidant activity of $M$. fragrans flesh extract is influenced by tannin, total flavonoid, and total phenolic contents about $89.23-97.63 \%$. It indicates that the three compound's contribution is very high so that the antioxidant activity of samples decreased significantly from $105.669 \pm 0.102$ to $387.536 \pm 1.687 \mu \mathrm{g} / \mathrm{mL}$ for the DPPH and $89.980 \pm 0.480$ to $481.778 \pm 2.124 \mu \mathrm{g} / \mathrm{mL}$ for ABTS method. Besides that, the correlation report 2.37$10.68 \%$ antioxidant activities may also come from other antioxidant secondary metabolites in the $M$. fragrans flesh extracts $^{49}$.

\section{CONCLUSION}

Myristica fragrans flesh extracts are classified as a strong antioxidant in scavenging the stable free radical ABTS ( $0 \% \mathrm{MfFE})$ and intermediate antioxidant in scavenging the stable free radical DPPH $(0 \%$ MfFE). The tannin, total flavonoid, and total phenolic contents strongly influence its antioxidant activity. Therefore, precipitation from the tannin - protein (egg white) bond caused antioxidant activities to decrease. 


\section{ACKNOWLEDGMENT}

The authors thank the Universitas Sam Ratulangi for the financial support via LPPM scheme Basic/Applied Research for Young Lecture Unsrat (RDTPU) by the research grant contract 173/UN12.13/LT/2021.

\section{AUTHORS' CONTRIBUTION}

Irma Antasionasti, Olvie Syenni Datu, and Utami Sasmita Lestari funded and conducted laboratory work for this study, which Surya Sumantri Abdullah assists. The first mentioned authors, as well as Irma Antasionasti, Olvie Syenni Datu, Utami Sasmita Lestari, Surya Sumantri Abdullah, and Imam Jayanto, contributed equally to conceptualization, data curation, formal analysis, project administration, resources, supervision, validation, visualization, writing an original draft, and writing review and editing. All authors read and approved the final manuscript.

\section{DATA AVAILABILITY}

All data are available from the authors.

\section{CONFLICT OF INTEREST}

There are no conflicts of interest.

\section{REFERENCES}

1. Gupta AD, Rajpurohit D. Nuts and Seeds in Health and Disease Prevention. Cambridge(MA): Academic Press; 2011. Chapter 98, Antioxidant and Antimicrobial Activity of Nutmeg (Myristica fragrans); p. 831-9. doi:10.1016/B978-0-12-3756886.10098-2

2. Morsy NFS. A comparative study of nutmeg (Myristica fragrans Houtt.) oleoresins obtained by conventional and green extraction techniques. J Food Sci Technol. 2016;53(10):3770-7. doi:10.1007/s13197016-2363-0
3. Abourashed EA, El-Alfy AT. Chemical diversity and pharmacological significance of the secondary metabolites of nutmeg (Myristica fragrans Houtt.). Phytochem Rev. 2016;15(6):1035-56. doi:10.1007/s11101-016-9469-x

4. Tan KP, Khoo HE, Azrina A. Comparison of antioxidant components and antioxidant capacity in different parts of nutmeg (Myristica fragrans). Int Food Res J. 2013;20(3):1049-52.

5. Piaru SP, Mahmud R, Majid AMSA, Nassar ZDM. Antioxidant and antiangiogenic activities of the essential oils of Myristica fragrans and Morinda citrifolia. Asian Pac J Trop Med. 2012;5(4):294-8. doi:10.1016/s1995-7645(12)60042-x

6. Sulaiman SF, Ooi KL. Antioxidant and anti foodborne bacterial activities of extracts from leaf and different fruit parts of Myristica fragrans Houtt. Food Control. 2012;25(2):533-6. doi:10.1016/j.foodcont.2011.11.005

7. Ginting B, Mustanir, Helwati H, Desiyana LS, Eralisa, Mujahid R. Antioxidant activity of n-hexane extract of nutmeg plants from South Aceh Province. J Natural. 2017;17(1):39-44. doi:10.24815/jn.v17i1.6969

8. Ginting B, Maira R, Mustanir, Helwati H, Desiyana LS, Mujahid R. Isolation of essensial oil of nutmeg (Myristica fragrans Houtt) and antioxidant activity test with DPPH. J Natural. 2018;18(1):11-7. doi:10.24815/jn.v18i1.6604

9. Ginting B, Saidi N, Murniana, Mustanir, Maulidna, Simanjuntak P. Lignan compound isolated from nhexane extract Myristica fragrans Houtt root as antioxidant and antitumor activities against MCF-7 cell lines data. Data Brief. 2020;31:105997. doi:10.1016/j.dib.2020.105997

10. Al-Jumaily EF, Al-Amiry MHA. Extraction and Purification of Terpenes from Nutmeg (myristica fragrans). Al-Nahrain J Sci. 2012;15(3):151-60. doi:10.22401/JNUS.15.3.21

11. Gupta AD, Bansal VK, Babu V, Maithil N. Chemistry, antioxidant and antimicrobial potential of nutmeg (Myristica fragrans Houtt). J Genet Eng Biotechnol. 2013;11(1):25-31. doi:10.1016/j.jgeb.2012.12.001

12. Periasamy G, Karim A, Gibrelibanos M, Gebremedhin G, Gilani AuH. Essential Oils in Food Preservation, Flavor and Safety. Cambridge (MA): Academic Press; 2016. Chapter 69, Nutmeg 
(Myristica fragrans Houtt.) Oils; p. 607-16. doi:10.1016/B978-0-12-416641-7.00069-9

13. Panggabean KA, Rusmarilin H, Suryanto D. The utilization of nutmeg seed (Myristica fragrans Houtt) extract as an antimicrobial on tempeh sausage. IOP Conf Ser Earth Environ Sci. 2018;260:012087. doi:10.1088/1755-1315/260/1/012087

14. Vivia SF, Trisnawati CY, Budianta DW. Pengaruh konsentrasi putih telur terhadap sifat fisikokimia dan organoleptik sari buah pala (Myristica fragrans Houtt). J Teknologi Pangan Gizi (J Food Technol Nutr). 2014;13(1):12-6. doi:10.33508/jtpg.v13i1.1495

15. Sung SH, Kim KH, Jeon BT, Cheong SH, Park JH, $\mathrm{Kim} \mathrm{DH}$, et al. Antibacterial and antioxidant activities of tannins extracted from agricultural by-products. J Med Plants Res. 2012;6(15):3072-9. doi:10.5897/JMPR11.1575

16. Park M, Cho H, Lee H, Hwang KT. Antioxidant and Anti-Inflammatory Activities of Tannin Fraction of the Extract from Black Raspberry Seeds Compared to Grape Seeds. J Food Biochem. 2013;38(3):259-70. doi:10.1111/jfbc.12044

17. Toul F, Belyagoubi-Benhammou N, Zitouni A, Ghembaza N, Atik-Bekkara F. In-vitro antioxidant effects of tannin extracts of Pistacia atlantica. Int J Pharm Sci Res. 2015;7(1):121-6. doi:10.13040/IJPSR.0975-8232.7(1).121-26

18. Maisetta G, Batoni G, Caboni P, Esin S, Rinaldi AC, Zucca P. Tannin profile, antioxidant properties, and antimicrobial activity of extracts from two Mediterranean species of parasitic plant Cytinus. BMC Complement Altern Med. 2019;19:82. doi:10.1186/s12906-019-2487-7

19. Srividya N, Chandra M. Evaluation of bioactive compounds and antioxidant activity of some wild fruits by in-vitro assays. Int J Pharm Sci Res. 2014;6(1):233-8. doi:10.13040/IJPSR.09758232.6(1).233-38

20. Canadianti M, Yusiati LM, Hanim C, Widyobroto BP, Astuti A. The Effect of Nutmeg Leaves Tannin (Myristica fragrans Houtt) as Protein Protecting Agents on In Vitro Nutrient Digestibility. Bul Peternak (Bull Anim Sci). 2020;44(1):10-4. doi:10.21059/buletinpeternak.v44i1.47976

21. Arina NB, Rohman A. The phenolic contents and antiradical activity of Indonesian Phyllantus urinaria L. Int Food Res J. 2013;20(3):1119-24.
22. Antasionasti I, Riyanto S, Rohman A. Antioxidant Activities and Phenolics Contents of Avocado (Persea americana Mill.) Peel in vitro. Res J Med Plants. 2017;11(2):55-61. doi:10.3923/rjmp.2017.55.61

23. Indriaty F, Assah YF. Pengaruh penambahan gula dan sari buah terhadap kualitas minuman serbuk daging buah pala. J Penelitian Teknologi Industri. 2015;7(1):49-60. doi:10.33749/jpti.v7i1.4683

24. Kikuzaki H, Hisamoto M, Hirose K, Akiyama K, Taniguchi $\mathrm{H}$. Antioxidant properties of ferulic acid and its related compounds. J Agric Food Chem. 2002;50(7):2161-8. doi:10.1021/jf011348w

25. Aktumsek A, Zengin G, Guler GO, Cakmak YS, Duran A. Antioxidant potentials and anticholinesterase activities of methanolic and aqueous extracts of three endemic Centaurea L. species. Food Chem Toxicol. 2013;55:290-6. doi:10.1016/j.fct.2013.01.018

26. Pratama M, Razak R, Rosalina VS. Analisis kadar tanin total ekstrak etanol bunga cengkeh (Syzygium aromaticum L.) menggunakan metode spektrofotometri UV-Vis. J Fitofarmaka Indones. 2019;6(2):368-73. doi:10.33096/jffi.v6i2.510

27. Chun OK, Kim DO, Lee CY. Superoxide radical scavenging activity of the major polyphenols in fresh plums. J Agric Food Chem. 2003;51(27):8067-72. doi:10.1021/jf034740d

28. Zou Y, Lu Y, Wei D. Antioxidant activity of a flavonoid-rich extract of Hypericum perforatum L. in vitro. J Agric Food Chem. 2004;52(16):5032-9. doi:10.1021/jf049571r

29. Fitriana WD, Fatmawati S, Ersam T. Uji Aktivitas Antioksidan terhadap DPPH dan ABTS dari Fraksifraksi Daun Kelor (Moringa oleifera). In: Irwanto D, Akbar FT, Aimon AH, editors. Prosiding Simposium Nasional Inovasi dan Pembelajaran Sains 2015 (SNIPS 2015); 2015 June 8-9; Bandung, Indonesia. Bandung: Program Studi Magister Pengajaran Fisika FMIPA ITB; 2015. p. 657-60.

30. Wootton-Beard PC, Moran A, Ryan L. Stability of the total antioxidant capacity and total polyphenol content of 23 commercially available vegetable juices before and after in vitro digestion measured by FRAP, DPPH, ABTS and Folin-Ciocalteu methods. Food Res Int. 2011;44(1):217-24. doi:10.1016/j.foodres.2010.10.033 
31. Ervina M, Nawu YE, Esar SY. Comparison of in vitro antioxidant activity of infusion, extract and fractions of Indonesian Cinnamon (Cinnamomum burmannii) bark. Int Food Res J. 2016;23(3):1346-50.

32. Assa JR, Widjanarko SB, Kusnadi J, Berhimpon S. Antioxidant Potential of Flesh, Seed and Mace of Nutmeg (Myristica fragrans Houtt). Int J ChemTech Res. 2014;6(4):2460-8.

33. Selonni F. The Effect of Drying Method on The Antioxidant Activity of The Flesh of Nutmeg. Indones J Pharm Res. 2021;1(1):1-6. doi:10.31869/ijpr.v1i1.2437

34. Kolla MC, Laya A, Bayang JP, Koubala BB. Effect of different drying methods and storage conditions on physical, nutritional, bioactive compounds and antioxidant properties of doum (Hyphaene thebaica) fruits. Heliyon. 2021;7(4):e06678. doi:10.1016/j.heliyon.2021.e06678

35. Platzer M, Kiese S, Herfellner T, Schweiggert-Weisz U, Miesbauer O, Eisner P. Common Trends and Differences in Antioxidant Activity Analysis of Phenolic Substances Using Single Electron Transfer Based Assays. Molecules. 2021;26(5):1244. doi:10.3390/molecules26051244

36. Martysiak-Żurowska D, Wenta W. A comparison of ABTS and DPPH methods for assessing the total antioxidant capacity of human milk. Acta Sci Pol Technol Aliment. 2012;11(1):83-9.

37. Schaich KM, Tian X, Xie J. Hurdles and pitfalls in measuring antioxidant efficacy: A critical evaluation of ABTS, DPPH, and ORAC assays. J Funct Foods. 2015;14:111-25. doi:10.1016/j.jff.2015.01.043

38. Richard T, Lefeuvre D, Descendit A, Quideau S, Monti JP. Recognition characters in peptidepolyphenol complex formation. Biochim Biophys Acta. 2006;1760(6):951-8. doi:10.1016/j.bbagen.2006.01.005

39. Budryn G, Nebesny E, Rachwal D. Pepsin Digestibility and Antioxidant Activity of Egg White Protein in Model Systems with Green Coffee Extract. Int J Food Prop. 2014;17(7):1529-46. doi:10.1080/10942912.2012.723235

40. Yin C, Yang L, Zhao H, Li CP. Improvement of antioxidant activity of egg white protein by phosphorylation and conjugation of epigallocatechin gallate. Food Res Int. 2014;64:855-63. doi:10.1016/j.foodres.2014.08.020
41. Sun J, Jing H, Liu T, Dong S, Obadi M, Xu B. Evaluation of antioxidant modification on the functional and structural properties of EWP conjugates. RSC Adv. 2020;10(18):10666-72. doi:10.1039/D0RA00023J

42. McRae JM, Kennedy JA. Wine and grape tannin interactions with salivary proteins and their impact on astringency: a review of current research. Molecules. 2011;16(3):2348-64. doi:10.3390/molecules16032348

43. Dieng SIM, Mathieu C, Sarr A, Diatta-Badji K, Fall AD. Condensed Tannins Content and their Influence on the Antioxidant Activity of Bark Hydroethanol Extract of Piliostigma reticulatum (Dc) Hochst and its Fractions. Pharmacogn J. 2020;12(2):361-8. doi:10.5530/pj.2020.12.57

44. Hidjrawan Y. Identifikasi senyawa tanin pada daun belimbing wuluh (Averrhoa bilimbi L.). J Optimalisasi. 2018;4(2):78-82. doi:10.35308/jopt.v4i2.1475

45. Antasionasti I, Jayanto I, Abdullah SS, Siampa JP. karakterisasi nanopartikel ekstrak etanol kayu manis (Cinnamomum burmanii) dengan kitosan sodium tripolifosfat sebagai kandidat Antioksidan. Chem Prog. 2020;13(2):77-85. doi:10.35799/cp.13.2.2020.31392

46. Kallel I, Hadrich B, Gargouri B, Chaabane A, Lassoued S, Gdoura R, et al. Optimization of Cinnamon (Cinnamomum zeylanicum Blume) Essential Oil Extraction: Evaluation of Antioxidant and Antiproliferative Effects. Evid Based Complement Alternat Med. 2019;2019:6498347. doi:10.1155/2019/6498347

47. Gülçin I, Huyut Z, Elmastaş M, Aboul-Enein HY. Radical scavenging and antioxidant activity of tannic acid. Arab J Chem. 2010;3(1):45-53. doi:10.1016/j.arabjc.2009.12.008

48. Treml J, Šmejkal K. Flavonoids as Potent Scavengers of Hydroxyl Radicals. Compr Rev Food Sci Food Saf. 2016;15(4):720-38. doi:10.1111/1541-4337.12204

49. Yamin Y, Ruslin R, Sabarudin S, Sida N, Kasmawati H, Diman LOM. Determination of Antiradical Activity, Total Phenolic, and Total Flavonoid Contents of Extracts and Fractions of Langsat (Lansium domesticum Coor.) Seeds. Borneo J Pharm. 2020;3(4):249-56. doi:10.33084/bjop.v3i4.1500 